\title{
The Incidence of Soil Erosion in Zing Local Government Area of Taraba State, Nigeria
}

\author{
Ray, H. H. ${ }^{*}$ and YUSUF, M. B. ${ }^{2}$ \\ http://dx.doi.org/10.4314/ejesm.v4i2.2
}

\begin{abstract}
The study sought to find out the extent of soil erosion on farmlands in Zing local government area, particularly rill and gully erosions. Ten years rainfall data (1996-2005); were obtained, while rill and gully parameters of 10 farms on the hill slopes, and 10 farms on flat lands were measured. Also laboratory analysis of the soils sampled from the 20 farms sites was conducted. The study revealed that rainfall in the area is erosive, while analysis of data on rills and gullies using the student $t$-test shows that greater length and depth of erosion occurs on the hill slope farmlands than on the flat land farmlands. This could be because though the hill slopes are steep and erosion can easily occur, in addition is that, farmers also practice arable farming extensively on them. The laboratory analysis however, established that there was no significant difference at $P=0.05$ in most of the physical and chemical properties of soils between the farmlands on the hill slopes and those on the plains. This could be because soils in this vicinity are from the same parent material.
\end{abstract}

Keywords: Erosion, Farmlands, Hill slope, Flatland, Zing.

\section{Introduction}

Soil erosion can be described as the process by which rock fragments and soil are detached from their original sites, transported; and eventually deposited at some new locality; (Ray, 1994; Adediji, 2000; Iguisi, 2002; Adebayo and Tukur, 2003). Soil erosion causes tremendous damage to about onethird of world's cropland (Hudson, 1989). Although, many erosion control technologies are available that are well understood and effective, yet the world soil erosion by water persists at levels greatly in excess of soil formation rates in most agricultural regions of the world, (Biswas and Narayanasamy, 1996). Erosion has assumed disastrous proportions in the mountainous regions due to increased intensification of various human activities in the later years (Ogidiolu, 2000). In Nigeria, for example, over $80 \%$ of the cropland regions are ravaged by erosion (NEST, 1999).

${ }^{1}$ Department of Geography, Federal University of Technology, Yola

*Corresponding author's e-mail: helenhumuoray@yahoo.com

${ }^{2}$ Department of Geography, Taraba State University, Jalingo
The mean annual loss of crop productive capacity through erosion is estimated to be 25 million tones; (Adediji, 2000). This has led to low yield, reduced grazing land for livestock, famine, low standard of living; and decrease in availability of fuel wood, food insecurity, poverty and migration of rural dwellers (Olatunji, 2003). The study area portrays a situation; where farmers work the hill slopes almost as much as the flat lands, even though there is available farmland on the plains

This paper therefore seeks to find out, the extent of soil erosion on both hill slopes and flat lands, with the aim of assessing quantitatively the devastating effects of soil erosion on farmlands in the two geomorphic sites. 


\section{Materials and Methods}

\section{The Study Area:}

The study was conducted in Zing Local Government Area, of Taraba state. Zing local government lies, between latitudes $8^{\circ} 45^{1}$ and $9^{\circ} 10^{1}$ $\mathrm{N}$ and longitudes $11^{\circ} 35^{1}$ and $11^{\circ} 50^{1} \mathrm{E}$ with a total area of $8671 \mathrm{~km}^{2}$.The area lies within the savanna grassland belt particularly in the Guinea savanna sub region,(Ogidiolu 2000). It has two distinct seasons-the rainy and dry seasons. The mean annual precipitation ranges from $819-1761 \mathrm{~mm}$. The onset of the rains is in April; with low amount but increases gradually reaching a maximum in August; from when the amount drops gradually with cessation in October. (Fig. 1).

According to Areola (1983), the study area is characterized by hydromorphic and ferruginous tropical soils, highly influenced by local variation in altitude and human interference. The soil type is of the mixture of loams and sands and on the hilly terrain there are deep loamy soils found in between rocks. Along the banks of streams and rivers are clay loamy soils which support the growth of a variety of crops in the area. On relief configuration, the study area is categorized into highland/mountain ranges and lowlands. The highlands occupy the southern region stretching from west to south in chains of mountain (shebshi mountains), with elevation ranging from an average of 1,800-2,400 meters above sea level. This occupies $40 \%$ of the area. The lowland which occupies about $60 \%$ of the region hosts most of the settlements in the region.

\section{Field Measurement}

Measurements for rill and gully length, width, and depth were carried out at the encounter of every rill and gully site within the sampled farms, using a graduated leveling staff and meter tapes. Farm sizes were taken using meter tapes while slope angle around the rill and gully sites were also taking using abney level.

\section{Soil Sampling}

In order to obtain soil samples, 10 farms on hill slopes; and 10 on gentle slopes were selected. From these farms, soil samples were collected. Soil samples were taken from two points in each site; and at $0-15$, and $1530 \mathrm{~cm}$; below soil surface. The soil samples were analyzed in the Soil Laboratory of the Department of Soil Science, Federal University of Technology Yola, where physical and chemical properties of the soils were determined.

\section{Laboratory Methods}

Particle size analysis was determined by air drying the soil samples and then passing them through $2 \mathrm{~mm}$ sieve. Using the hydrometer method as described by Bouyocous (1926), Percentage silt, sand and clay were determined using textural triangle of IITA (1976), while the water holding capacity was determined by gravimetric method.

Soil $\mathrm{pH}$ was measured in a 1: 2.5 soil: water suspension ratio with the use of a glass electrode $\mathrm{pH}$ meter. The electrical conductivity (EC) of the samples was determined in sequence alongside the $\mathrm{pH}$ in the same suspension using an EC meter. The organic carbon $(\mathrm{O} ; \mathrm{C})$ was determined using potassium dichromate wet-oxidation method of Walkley and Black (1934). The soil organic matter was obtained by multiplying the $\mathrm{O}$; $\mathrm{C}$ with a conversion factor of 1.724. Total nitrogen $(\mathrm{N})$ was determined by Kjeldahl method (Bremner and Mulvaney, 1982); while the available phosphorus $\mathrm{P}_{2} \mathrm{O}_{5}$ by Bray 1 method (Bray and Kurtz, 1945). The available potassium $\left(\mathrm{K}_{2}\right)$ and sodium $(\mathrm{Na})$ by flame photometry (Jackson, 1965); while the exchangeable calcium $(\mathrm{Ca})$ and magnesium $(\mathrm{Mg})$ were determined by the Tetrameteric method. Data collected were summarized using descriptive statistics in addition to $\mathrm{t}$ - test analysis. 


\section{Results and Discussion}

\section{Rainfall Intensity}

From table 1,pp.14, it can be observed that year 1998, had the lowest number of rainy days with precipitation greater than $20 \mathrm{~mm}(29.7 \%)$ while 2002 had the highest total number of days with precipitation greater than $20 \mathrm{~mm}$ value of $62.7 \%$. All the years had above 29 percent. This indicates that all the years had rainfall greater than $20 \mathrm{~mm}$ as percentage of annual total.

Kowal and kassam (1977) in their study of surface run-off and soil erosion from cultivated areas of gentle and long slopes observed that all storms with rainfall greater than $20 \mathrm{~mm}$ resulted in run-off. Hence, all storms greater than $20 \mathrm{~mm}$ were regarded as erosive in this study. With this suggestion, it can be argued that rain fall in the study area is generally erosive

\section{Field Measurement of rill and gully parameters}

Table 2 and 3, pp.15\&16, reveals that, farm sizes are bigger on flat lands than on hill slopes. The number of rills and gullies found on the slope farmlands are greater than those on the plains. Slope lengths are more on the hill slopes as indicated on Table 2. .They had lengths as long as $226 \mathrm{~m}$ in Buduga,and $205 \mathrm{~m}$ in Kakulu . All lengths were above $100 \mathrm{~m}$, except in Yali and Laapo. On flat lands, no slope length was up to $150 \mathrm{~m}$ long as shown on Table 3.The longest was $110 \mathrm{~m}$ long, even where farm sizes were bigger. The same disparity is shown for width and depth. The widest was $3.9 \mathrm{~m}$ at zing on hill slopes while on flat lands it was $2.8 \mathrm{~m}$. The deepest was $2.8 \mathrm{~m}$ in zing on hill slopes and $1.8 \mathrm{~m}$ in yakoko on flat lands. Also, the farmers cultivate chiefly the same types of crops, except for the fact that guinea corn was slightly grown more on the flat lands.

Table 4, pp16, shows the summary of rill and gully parameters between the hill slopes and flat land farmlands as analyzed by student $t$ test. This shows statistically the disparity between the hill land farms. There were variations in the mean values of rill and gully parameter over the two farm sites. With the mean values of the hill slope farmlands greater than those of the flat farmlands, meaning erosion was more prone on the hill slopes than the flat farmlands. Similarly, the t-test computation reveals that there was a significant difference in the rill and gully parameters between the two farm sites in terms of their length and depth. This cannot be unconnected with the differences in the nature of the terrain as can be seen with the measurement of slope angles of the areas in Table 2 and 3, which has a principal influence on the amount of run-off from rain water to increase with increases in slope.

\section{Status of Soils and Soil Erosion}

From table 5, pp 17, the mean values of the soil physical properties seems to be homogeneous and almost uniform. Using the student $t$-test, there was no significant difference at $\mathrm{P}=0.05$ in all but one property between the two sites studied. This is not surprising as the soils are made up chiefly of sandy loam texture and are low in organic matter content, which is the principal factor responsible for holding water in the soil. The t-test result shows that, there was no significant difference in the soil $\mathrm{pH}$, organic matter content, electrical conductivity (EC) and total nitrogen, but there was a significant difference with respect to available phosphorus and total exchangeable bases (TEB) with the hill slope farms having greater than the flatland farms. This could probably be attributed to the fact that hills or mountains are the sources of all minerals and weathering process take place almost continuously to release the TEB as they are leached out (Kaihura et al 1999).

There were generally little or no differences between the physio-chemical properties of soils on the hill slope and those on the flat land farm lands. This could probably be the reasons why farmers in the study area use both the hill slopes and the flatlands for Agriculture. 


\section{Conclusion}

The main focus of this study was to find out the extent of soil erosion on farmlands in Zing Local Government Area particularly rills and gully erosions. Therefore, rainfall analysis was undertaken, which showed that rainfall in the area was generally erosive with between $50 \%$ and $90 \%$ $\mathrm{mm}$ as percentage of annual total. The field measurement computation and t-test result on the rill and gully parameters showed that greater length and depth of erosion occurred on hill slope farmlands than on flat farmlands. This is not far from what Ogidiolu (2000), also found in his studies that soil erosion assumed disastrous proportion in the mountainous region due to increased intensification of various human induced activities in the later years. There was no significant difference in most of the physical and chemical properties measured between the two farm sites of the study area. This could be attributed to the fact that soils are principally from the same parent material, and crops grown are the same type as shown on table 2 and 3.

\section{REFERENCES}

Adebayo, A.A. and Tukur, A.L (2003), Farmers Perception of Environmental Problems in Adamawa State, Nigeria. Tropical Journal of Environmental Management, (1), 52-61.

Adediji, A. (2000), The Politics on Erosion Issues. In Jimoh, H. I. and Ifabiyi, I. P. (eds.), Contemporary Issues in Environmental Studies. Haytee and Publishing Comp. Ilorin,Kwara, State Nigeria.

Areola, O. (1983), Soil and Vegetation Resources: A Geography of Nigeria Development, Heinemann, Ibadan.
Biswas, T.D and Narayanasamy, G. (1996), Soil Management in Relation to Land Degradation and Environment. Bulletin No 17. Indian Society of soil Science, New Delhi.

Hudson N.W (1989), Soil Conservation, B.T Brantford Limited, London.

Iguisi E.O. (2002), An Assessment of Temporary Variation in Soil Loss within Hydrological year. The Zaria Geographer, 15(1), 125-133.

Kowal, J.M and Kssam, A.H (1977), Energy Load and Instantaneous Intensity of Rainstorms at Samaru,Northern Nigeria, in Ray, S. (2005), An Appraisal of Crop Production Practices and Crop Productivity among Farmers in Mubi and Environs: Ph.D thesis submitted to Bayero University, Kano.

Nigerian Environmental Study/ Action Term (NEST), (1999), Nigerians Threatened Environment: A National Profile: NEST, Publications, Ibadan.

Ogidiolu, A. (2000), Assessment of Soil Degradation Under Agricultural Land Uses in part of Savannah Region of Nigeria. Journal of Environmental Reviews, 3(1), 117 -129.

Olatunji, O.J (2003), The Effect of Socio Characteristic of Farmers on Land Degradation in the Derived Guinea-Savannah Ecological Zone of Nigeria. International Journal of Environmental Issues, 1(1), 237-241.

Ray, H.H. (1994), Soil Conservation; Introductory Notes for Adamawa Agricultural Development Programme Extension Agents: Synothetyme Communication, Ltd, Yola. 
The Incidence of Soil Erosion in Zing......... Ray and YUSUF EJESMVol. 4 No.2 2011

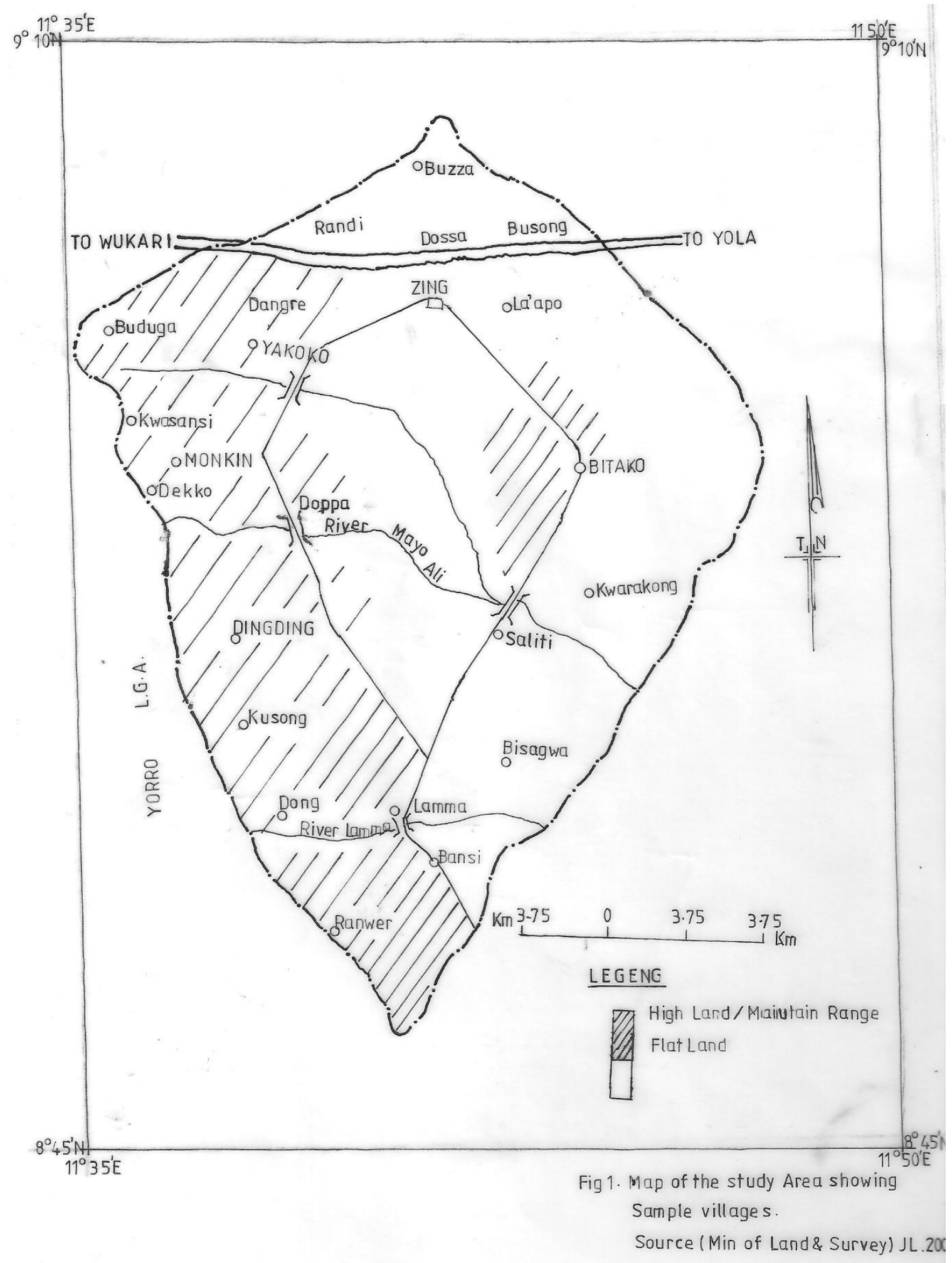


Table 1 shows the percentages of the number of rainy days with storms greater than $20 \mathrm{~mm}$ as against the total number of rainy days.

Table 1: The percentage of rainy days with storms greater than $20 \mathrm{~mm}$ as against the total rainy daysfrom1995 - 2005 in Zing Local Government Area

\begin{tabular}{|c|c|c|c|}
\hline years & Number of rainy days & $\begin{array}{l}\text { Number of days with storms } \\
\text { greater than } 20 \mathrm{~mm}\end{array}$ & 2 as percentage of 1 \\
\hline 1995 & 51 & 26 & 38.1 \\
\hline 1996 & 64 & 27 & 32.7 \\
\hline 1997 & 56 & 25 & 45.4 \\
\hline 1998 & 44 & 22 & 29.7 \\
\hline 1999 & 42 & 24 & 42.7 \\
\hline 2000 & 36 & 15 & 40.0 \\
\hline 2001 & 37 & 22 & 56.1 \\
\hline 2002 & 40 & 26 & 62.7 \\
\hline 2003 & 45 & 26 & 40.1 \\
\hline 2004 & 43 & 29 & 47.5 \\
\hline 2005 & 26 & 19 & 60.3 \\
\hline Total & 484 & 261 & 495.3 \\
\hline Mean & 44.0 & 23.7 & 45.0 \\
\hline
\end{tabular}

Source: Calculated from data obtained from Taraba Agricultural Development Programme Zone 1 Zing 
Table 2 Rill and Gully parameters of the 10 selected Farm site on Hill Slope Areas

\begin{tabular}{|l|l|l|l|l|l|l|l|l|l|}
\hline & & & & & \multicolumn{3}{l|}{ Rill and gully parameters } \\
\hline Districts & Villages & $\begin{array}{l}\text { Farm } \\
\text { Size } \\
\text { (Ha) }\end{array}$ & $\begin{array}{l}\text { Land } \\
\text { Use }\end{array}$ & $\begin{array}{l}\text { No. } \\
\text { of } \\
\text { Rills }\end{array}$ & $\begin{array}{l}\text { No. of } \\
\text { gullies }\end{array}$ & $\begin{array}{l}\text { Slope } \\
\text { Length (m) }\end{array}$ & $\begin{array}{l}\text { Slope } \\
\text { Average } \\
\text { Width } \\
(\mathrm{m})\end{array}$ & $\begin{array}{l}\text { Slope } \\
\text { Average } \\
\text { Depth } \\
(\mathrm{m})\end{array}$ & $\begin{array}{l}\text { Slope } \\
\text { Angle }(\%)\end{array}$ \\
\hline Lamma & Dong & 0.5 & Yam & 13 & 2 & 121.2 & 2.7 & 2.2 & 4.5 \\
\hline & Rangwere & 0.9 & Yam & 10 & 4 & 117.2 & 2.8 & 2.3 & 4.0 \\
\hline Monkin & Dekko & 0.7 & Yam & 8 & 3 & 141.5 & 3.4 & 2.6 & 3.0 \\
\hline Yakoko & Kuduga & 0.5 & Yam & 8 & 1 & 226.0 & 3.1 & 2.1 & 4.5 \\
\hline Bitako & Ibrahim & 0.5 & G/Corn & 10 & 2 & 120.0 & 2.1 & 1.4 & 2.0 \\
\hline Zangwe & 0.5 & Yam & 9 & 3 & 154.0 & 1.6 & 1.7 & 3.0 \\
\hline Bubong & La'apo & 0.5 & Yam & 8 & 3 & 85.0 & 1.6 & 1.5 & 1.5 \\
\hline Mean & Kakulu & 0.7 & Yam & 10 & 2 & 205.0 & 3.9 & 2.8 & 2.5 \\
\hline
\end{tabular}

Source: Field survey 2007 
Table 3 Rill and Gully parameters of the 10 selected Farm site on Flat Land Areas

\begin{tabular}{|c|c|c|c|c|c|c|c|c|c|}
\hline & & & & & & \multicolumn{4}{|c|}{ Rills and Gullies parameters } \\
\hline Districts & Villages & $\begin{array}{l}\text { Farm } \\
\text { Size } \\
(\mathrm{Ha})\end{array}$ & Land Use & $\begin{array}{l}\text { No } \\
\text { of } \\
\text { Rills }\end{array}$ & $\begin{array}{l}\text { No. of } \\
\text { Gullies }\end{array}$ & $\begin{array}{c}\text { Slope } \\
\text { Length } \\
\text { (m) }\end{array}$ & $\begin{array}{c}\text { Slope } \\
\text { Average } \\
\text { Width } \\
\text { (m) }\end{array}$ & $\begin{array}{c}\text { Slope } \\
\text { Average } \\
\text { Depth (m) }\end{array}$ & $\begin{array}{c}\text { Slope } \\
\text { Angle } \\
(\%)\end{array}$ \\
\hline Lamma & Bansi & 1.5 & G/Corn & 6 & 1 & 110.5 & 2.4 & 1.6 & 2.0 \\
\hline & Bisagwa & 1.4 & G/Corn & 7 & 3 & 107.6 & 2.0 & 0.9 & 2.5 \\
\hline Monkin & Dosheti & 1.4 & G/Corn & 8 & 2 & 101.4 & 2.4 & 1.3 & 1.5 \\
\hline Yakoko & Della & 1.0 & Yam & 10 & 1 & 95.2 & 1.6 & 1.8 & 1.0 \\
\hline & $\begin{array}{l}\text { Bishom- } \\
\text { Porong }\end{array}$ & 1.2 & Yam & 9 & 2 & 102.7 & 2.0 & 1.0 & 1.5 \\
\hline Bitako & Korakong & 1.3 & Yam & 6 & 1 & 90.1 & 1.4 & 0.7 & 1.5 \\
\hline Bubong & Buzza & 1.4 & Yam & 8 & 1 & 78.3 & 2.8 & 1.4 & 1.5 \\
\hline & Busong & 1.6 & Yam & 10 & 2 & 100.2 & 1.1 & 1.2 & 2.0 \\
\hline Zing & Zandi & 1.8 & Yam & 9 & 2 & 109.0 & 2.1 & 0.8 & 2.5 \\
\hline & Dossa & 1.5 & G/Corn & 5 & 2 & 73.0 & 0.5 & 0.9 & 1.0 \\
\hline Total & & & & 78 & 17 & 968.0 & 18.2 & 11.6 & 17.0 \\
\hline Mean & & & & 7.8 & 1.7 & 96.8 & 1.8 & 1.2 & 1.7 \\
\hline
\end{tabular}

Source: Field survey 2007 
Table 4: Summary of t-test for Rill and Gully Parameters between the Hill slope and Flat land Farmlands

\begin{tabular}{|l|c|c|c|l|}
\hline Parameters & $\begin{array}{c}\text { Hill slope farm } \\
\text { Mean }\end{array}$ & $\begin{array}{c}\text { Flat land farm } \\
\text { Mean }\end{array}$ & t-value & Remark \\
\hline Length & 140.79 & 96.80 & 2.659 & Significant \\
\hline Width & 2.520 & 1.780 & 2.033 & Not significant \\
\hline Depth & 2.030 & 1.160 & 4.585 & Significant \\
\hline Slope angle & 3.00 & 1.73 & 3.528 & Significant \\
\hline
\end{tabular}

Source: Field survey, (2007). 
Table 5: Summary of t-test of the Variability in Soils Physio-chemical Properties

\begin{tabular}{|c|c|c|c|c|}
\hline Properties & $\begin{array}{l}\text { Hill slope farm } \\
\text { Mean }\end{array}$ & $\begin{array}{l}\text { Flat land farm } \\
\text { Mean }\end{array}$ & t-value & Remark \\
\hline Sand & 71.3 & 74.0 & -0.718 & Not significant \\
\hline Silt & 17.7 & 17.3 & 0.000 & Not significant \\
\hline Clay & 10.9 & 8.3 & 4.000 & Not significant \\
\hline $\begin{array}{lll}\text { Water } & \text { holding } & \text { capacity } \\
(\mathrm{WHC}) & & \end{array}$ & 40.47 & 39.16 & 5.861 & Significant \\
\hline Textural class & Sandy loam & Sandy loam & & \\
\hline Soil pH & 6.5 & 6.1 & 3.018 & Not significant \\
\hline Organic matter & 22.29 & 24.9 & 0.579 & Not significant \\
\hline $\begin{array}{l}\text { Electrical Conductivity } \\
\text { (EC) }\end{array}$ & 0.142 & 0.120 & 1.880 & Not significant \\
\hline Total nitrogen & 0.32 & 0.42 & 2.636 & Not significant \\
\hline Available phosphorous & 0.12 & 0.27 & 5.196 & Significant \\
\hline $\begin{array}{c}\text { Total exchangeable } \\
\text { Bases(TEB) }\end{array}$ & 4.18 & 0.33 & 10.270 & Significant \\
\hline
\end{tabular}

Source: Field survey, (2007) 